by unequal settling of the beds and variations in thickness of groups of beds ; they are not attributable to folding of the strata. Moreover, there is no apparent relation between structure and presence or absence of producing horizons. Accumulations of natural gas appear to be due to the porous character of certain beds and the existence of small decreases in dip within circumscribed areas.

There is no evidence to indicate that features favourable to the accumulation of natural gas are confined to those parts of the southern area already in production, neither has sufficient exploratory work been carried out to define by dry holes limits of fields now in operation. It would appear, therefore, that investigations could usefully be carried out both in the northern part of Brantford area where the Guelph and Trenton formations in certain districts offer prospects of production, and also in the several untested, or apparently untested, parts intervening between existing wells in the southern part of the area.

\section{STORAGE OF AUSTRALIAN APPLES}

$\mathrm{T}$ HE Jonathan apple is the chief variety exported from Victoria, between 600,000 and 700,000 bushels being sent overseas annually. Large quantities are also kept in cool storage for local consumption. Two or three pickings are made at fortnightly intervals, the earlier fruits, which are usually green, immature and acidic being exported. The large portion of the crop is picked in a late stage of maturity and considerable wastage occurs due to physiological breakdowns and moulds. With the object of reducing this wastage. Trout, Tindale and Huelin (Bull. No. 135, Australian Coun. Sci. and Ind. Res., 1940) have carried out an intensive study of the effect of different factors on keeping quality. The most important are maturity at the time of picking, seasonal and growing conditions, size of the fruit and crop, conditions immediately after picking, and conditions during storage. The ground colour of the fruit is a good index of the stage of maturity in a given district. Immature fruit is not very susceptible to storage disorders, but soft scald and breakdown are more frequent the longer the fruit is left on the tree. 'Jonathan Spot' develops in both immature and over-mature fruit. Soft scald is greatest between June and July and at $32^{\circ} \mathrm{F}$. It can be controlled by storage at $36^{\circ}-37^{\circ} \mathrm{F}$. The most mature fruit is most susceptible to breakdown, which is greatest at $32^{\circ} \mathrm{F}$.

Mould and Jonathan Spot are greater at higher storage temperatures. Susceptibility to soft scald is increased by short periods at $55^{\circ} \mathrm{F}$. and $65^{\circ} \mathrm{F}$., before transfer to storage at $32^{\circ} \mathrm{F}$., but decreases with longer periods. Cooling to $36^{\circ}-45^{\circ} \mathrm{F}$. immediately after picking is recommended, though the available cool storage space is at present a problem. Storage life can be prolonged by using an atmosphere containing 5 per cent carbon dioxide and 16 per cent oxygen at $36^{\circ} \mathrm{F}$. Brownheart occurs with greater concentrations of carbon dioxide. Short treatment with 36 per cent carbon dioxide reduces subsequent soft scald at $32^{\circ} \mathrm{F}$. but increases breakdown and Jonathan Spot. The ratio of cane sugar to acid in the fruit is correlated with keeping quality and with the ground colour at picking time.

\section{FORTHCOMING EVENTS}

[Meetings marked with an asterisk are open to the public.]

Monday, May 26

Royal Geographical Society (at the Cinema Theatre of the Imperial Institute, South Kensington, London, S.W.7), at 5 p.m.-Colour and Sound Films of India by the Lawrence Thaw. Expedition, and of Burma by Mr. Nathan.

\section{Tuesday, May 27}

Royal Institution of Great Britain (at 21 Albemarle Street, London, W.1), at 5.15 p.m.-Dr. C. F. A. Pantin, F.R.S. : "The Origin of Life".*

Wednesday, May 28

Institute of Metals (at the New Clarendon Laboratory, Oxford), at 3.30 p.m.-Dr. F. Simon, F.R.S. : "The Significance of Low Temperature Research" (Thirty. first Annual May Lecture).

\section{Thursday, May 29}

Royal Institution of Great BRItain (at 21 Albemarle Street, London, W.1), at 5.15 p.m.-Mr. W. H. Ansell : "The Re-Planning of London".*

Friday, May 30

Prysical Society (at the Lecture Theatre of the Science Museum, Exhibition Road, London, S.W.7), at 5 p.m.Dr. H. Spencer Jones, F.R.S. : "The 200-inch Telescope" (Twelfth Thomas Young Oration).*

\section{APPOINTMENTS VACANT}

APPLICATIONS are invited for the following appointments on or before the dates mentioned:

Sentor LECTURER IN ENGINERRING in the Oxford Schools of Technology, Art and Commerce-The Chief Education Officer, City Education Office, 77 George Street, Oxford (June 3).

BOROEGH EuEctrical ENGINGer-The Town Clerk, Guildhall, Maidenhead (endorsed 'Borough Electrical Engineer') (June 5).

ENGINEER for the Government of Sierra Leone Public Works Depart ment-The Crown Agents for the Colonies, 4 Millbank, London, S.W.1 (quoting $\mathrm{M} / 9552$ ).

LeCtURER IN BIOLOgY WITH some HygIene-The Principal, Training College, Hereford.

LECTURER IN Elfotrical ENgINERRING in the Norwich CollegeThe Director of Education, City Hall, Norwich.

SECRETARY-The Director of Research, British Launderers' Research Association, The Laboratories, Hill View Gardens, Hendon, London, N.W.4.

Maintanance Engineer for the Transport and Harbours Department of the British Guiana Government-The Crown Agents for the Colonies, 4 Millbank, London, S.W.1 (quoting M/9393).

\section{REPORTS AND OTHER PUBLICATIONS}

(not included in the monthly Books Supplement)

\section{Great Britain and Ireland}

Transactions of the Royal Society of Edinburgh. Vol. 60, Part 2, No. 11: On a World Correlation of the Pleistocene. By T. T. Paterson Pp. 373-425. (Edinburgh and London: Oliver and Boyd.) 68. 6d. [15 Quarterly Journal of the Royal Meteorological Society. Vol. 67, No. 289: The Phenological Report, 1940. Pp. 67-98. (London? Royal Meteorological Society.) 38 .

London Shellac Research Bureau. Technical Paper No. 20:

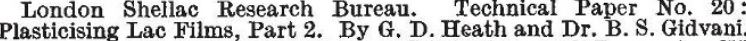
Plasticising Lac Films, Part 2. By G. D. Heath and Dr. B. S. Gidvani.
Pp. 14 +2 plates. (London: London Shellac Research Bureau.) [55 Pp. 14+2 plates. (London: London Shellac
Other Countries

Imperial Council of Agricultural Research. Miscellaneous Bulletin No. 46: A Brief Survey of some of the Important Breeds of Cattle in India, Part 3: Prize Winners at the Second and Third All-India Cattle Shows. Pp. iii $+30+34$ plates. (Delhi: Manager of Publications.) 2 rupees; 38 .

Canada: Department of Mines and Resources: Mines and Geology Branch, Bureau of Geology and Topography : Geological Survey. Memoir 224: Palmezoic Geology of the Toronto-Hamilton Area Ontario By J. F. Caley. (No. 2456.) Pp. iv +284. 75 cents. Memoi 225: The Picton Coalfield, Nova Scotia. By W. A. Bell. (No. 2457.) Pp. v $+142+10$ plates. 50 cents. (Ottawa: King's Printer.) 